\title{
ZIMÁNYI ÁRPÁD
}

\section{A KÖZOKTATÁSI INTÉZMÉNYEK MAI NÉVFORMÁI}

\section{Bevezetés}

A tanárképzésben, különösen a magyartanárok képzésében közreműködő oktatók számára kiemelt fontosságú részterület a helyesírás. Bár alapvető készségről van szó, a felsőoktatásban is bőven akad még tennivaló, többek között a nélkülözhetetlen leíró nyelvtani háttéranyag elmélyítésében, vagy például a szabályok közötti összefüggések bemutatása kapcsán. A helyesírás elméletének és gyakorlatának, valamint a magyar nyelv tantárgy-pedagógiájának elismert múvelője ünnepeltünk, Bozsik Gabriella, akinek neve és munkássága az elmúlt közel négy évtizedben összeforrott egri intézményünk nyelvészeti tanszékével. Kutatásai során többször foglalkozott az intézménynevek írásmódjával. A felsőoktatási intézmények Nagy J. Béláról elnevezett helyesírási versenyének egyik konferenciakötetében Az intézménynevek helyesírásának alakulása az akadémiai helyesírási szabályzatok alapján (1832-1994) címmel jelent meg átfogó tanulmánya (Bozsik 1999-2000). Ebben részletesen bemutatja, hogy - a társadalmi változásokat és a nyelvhasználatot követve - miképpen bővült a tulajdonnevek csoportjának ezen alpontja. Jelen vizsgálatunk még szűkebb területre irányul: a közoktatási intézmények, tehát az általános iskolák és a középiskolák mai névformáival foglalkozunk. Feltétlenül indokolt körüljárni ezt a témát, ugyanis az utóbbi két évtizedben ilyen tárgyú elemzések nem készültek, pedig a névanyag változása szembeszökő. Az állapotfelmérésből levont következtetések jól hasznosíthatók egyfelől az oktatási folyamatban, másfelől pedig hallgatóink, tehát a majdani tanárok számára a gyakorlati munkában.

Összefoglalásunk két fő részből áll: először a kodifikációról ejtünk szót, azaz röviden áttekintjük a szabályzatok és a helyesírási kézikönyvek releváns pontjait és példáit, majd a korpusz elemzésével névtipológiai megállapításokat teszünk.

\section{A szabályzati háttér}

Az akadémiai szabályzatokat áttekintve megállapíthatjuk, hogy az intézménynevek között iskolanévi példa első ízben az 1954-es kiadású AkH. ${ }^{10}$-ben szerepel: Vésztői Általános Iskola, Petőfi Sándor Gimnázium. Az 261. pont érdemleges megállapítást tesz, miszerint az intézménynevek minden „lényeges” szavát nagy kezdőbetűvel írjuk. A későbbi értelmezések szerint nem tekinthető lényegesnek többek között a számú, úti stb. szó, ezért pl. a II. sz./számú Általános Iskola vagy a Fazekas úti Általános Iskola hivatalos („cégszerü”) nevét ebben a formában írták. 
A "lényeges" fogalma körüli viták miatt a három évtizeddel későbbi AkH. ${ }^{11}$ 187. pontja egyértelművé tette a szabályt: „[...] az és kötőszó, valamint a névelők kivételével minden tagot nagybetúvel kezdünk." Ennek megfelelően változott a számú, úti stb. szavakat tartalmazó iskolanevek írása, és a szabálypont példasorába belekerült a Géza Király Téri Egészségügyi Szakközépiskola. A számmal jelölt iskolák nevének írásmódját analóg példa, a 43. Sz. Épitőipari Vállalat szemléltette.

Az utóbbi alakulatnál maradva: érdemes volt egy kisebb korrekciót végrehajtani a 11. kiadás 11. lenyomatától kezdve (1994-től: „Szótári anyagában bővített lenyomat" alcímmel), ahol az időközben megszűnt 43. Sz. Építőipari Vállalat névformáját a 138. Sz. Ipari Szakközépiskola és Szakmunkásképző példája váltotta fel. Érthető módon a szabályzat legújabb kiadásából $\left(A k H .{ }^{12}\right)$ már az utóbbi is kimaradt, hiszen - ahogy korpuszunk bizonyítja - manapság nem jellemző a számmal jelölt névtípus, sőt időközben a szakmunkásképző intézetek is átalakultak. Az AkH..$^{11 / 11}$ és az AkH. ${ }^{12}$ szótári részében további iskolanevekkel is találkozunk: az általános iskola bokra tartalmazza a Kavicsos Közi Általános Iskola és a Petöfi Sándor Általános Iskola alakulatokat.

A szabályok továbbgondolása, tágabb értelmezése kapcsán érdemes sorra venni a Magyar helyesírási szótárak (MHSz. ${ }^{1999 ;}$ MHSz. ${ }^{2017}$ ) iskolanévi példáit is. Az MHSz. ${ }^{1999}$ általános iskola bokra többféle névtípust, így több helyesírási problémahelyzetet szemléltet: Ceglédi IV. Sz. Általános Iskola, Aga Utcai Általános Iskola, József Attila Általános Iskola, Október 23. Utcai Általános Iskola, Petőfi Sándor Általános Iskola. Az utóbbi folytatásaként olvashatjuk a következő kitételt: "de röviden: Petőfi Sándor-iskola, Petőfi-iskola". Ez a forma az írásgyakorlatban nem gyökeresedett meg, és az $\mathrm{AkH} .{ }^{12}$ szellemében felülvizsgált újabb kiadás (MHSz. ${ }^{2017}$ ) már nem tartalmazza. Való igaz: az AkH. ${ }^{12}$ szabályai nem utalnak a tulajdonnév, illetve az intézménynév efféle kötőjeles tömörítésére. Saját intézményünk korábbi és jelenlegi nevével is alátámaszthatjuk, hogy nem vált közhasználatúvá az ily módon rövidült forma: Eszterházy Károly Főiskola *Eszterházy-főiskola; Eszterházy Károly Egyetem - ${ }^{*}$ Eszterházy-egyetem. (De: egri föiskola, egri egyetem.)

Az MHSz. ${ }^{2017}$ általános iskola címszavának példasorát a következőképpen igazították a mai névadási szokásokhoz: Brassó Utcai Általános Iskola, Hatvani 5. Számú Általános Iskola, József Attila Általános Iskola, Köztársaság Téri Általános Iskola, Örmezei Általános Iskola. Nem társul tulajdonnévi alakulat a szakközépiskola címszavához, de a középiskola bokra kissé bővebb: középiskola, szakközépiskola, gyakorló középiskola, Neumann János Középiskola és Kollégium. A mai iskolanévadási gyakorlatban problémát okozó - egybe- és különírási - eseteket rögzít az MHSz. ${ }^{2017}$ gimnázium bokra: gyakorlógimnázium, reálgimnázium, szakgimnázium, humán gimnázium, nyolcosztályos gimnázium, Petőfi Sándor Gimnázium. Az AkH. ${ }^{11}$ 112., illetőleg az AkH..$^{12}$ 118. pontja alapján rá kell mutatnunk a gyakorló középiskola és a gyakorlógimnázium eltérő írásmódjára (vö. alább, a Gyakorlóiskolák c. pont névanyagával).

A teljesség kedvéért megjegyezzük, hogy sem az AkH. ${ }^{12}$, sem pedig az MHSz. ${ }^{2017}$ szakközépiskola címszava nem tartalmaz tulajdonnévi példát. 
Közel hét évtized szabályzattörténetét áttekintve megállapíthatjuk, hogy a példák természetszerűleg az adott kor névadási gyakorlatát tükrözték, egyszersmind azt is láthatjuk, hogy az $\mathrm{AkH} .{ }^{12}$ és az MHSz. ${ }^{2017}$ iskolanévi példasorai a korábbiaknál bonyolultabb esetekre is kiterjednek. De hogy ez mennyire adja vissza a 2020-as helyzetet, arra a következő névtipológiai fejezet adja meg a választ.

\section{Korpusz és munkamódszer}

Az elemzéshez a www.iskolaklistaja.eu (W1) 3135 nevet tartalmazó adatbázisát használtam. A korpusz szembetűnő sajátossága, hogy rendkívül sokszínű az általános és a középiskolák névformája, névszerkezete - ez adta az ötletet a névtipológiai vizsgálat elkészítéséhez. A különböző típusokat nem vetettem alá statisztikai elemzésnek, ezért a hatalmas adatbázisból válogató jelleggel emeltem ki a szemléltető példákat. Mivel ez nem hivatalos lista, második lépésként ellenőriztem a névalakulatokat a Nemzeti Pályaorientációs Intézet (W2), valamint a Közösségi Szolgálat (W3) - szintén adatbázisokat tartalmazó - portálján, bizonytalan esetekben pedig az adott intézmény honlapján. Az utóbbi helyen általában megtalálható az alapító okirat, illetőleg az intézmény szervezeti és múködési szabályzata, amelyek a hivatalos formát tartalmazzák. (Nem perdöntő egy adott intézmény Facebook-oldala, ahol esetenként az iskolai honlapon szereplőtől, illetőleg az intézményi dokumentumokban rögzítettől eltérő, rövidebb, közkeletű névformával találkozunk.)

\section{Névtipológia}

\subsection{Hagyományos névtípusok - egyszerü nevek}

Kisebb számban vannak még az 1990 előtti gyakorlatot folytató iskolanevek, amelyek mindenekelőtt rövidségükkel tűnnek föl. Ezek lehetnek:

- a településnevet jelzőként tartalmazó névformák, jellemzően általános iskolák, kisebb számban középiskolák (Rétsági Általános Iskola; Cinkotai Szakközépiskola);

- városrésznévvel megkülönböztetett intézménynevek (Avasi Gimnázium; Óbudai Gimnázium);

- településnévi jelzővel és számmal megkülönböztetett iskolanevek (Százhalombattai 1. Számú Általános Iskola; Budaörsi 1. Számú Általános Iskola);

- Személynevet tartalmazó rövid alakulatok (Arany János Általános Iskola; Gárdonyi Géza Általános Iskola; Árpád Gimnázium), ritkán a névadó doktori fokozatának feltüntetésével (Dr. Berze Nagy János Óvoda és Általános Iskola; Dr. Tolnay Sándor Általános Iskola);

- római számmal megkülönböztetett uralkodó nevét tartalmazó alakulatok (I. Rákóczi György Gimnázium; II. Géza Gimnázium; III. Béla Szakképző Iskola és Kollégium); 
- ünnepnapot dátumszerűen tartalmazó névalakulat (Március 15. Gimnázium, Szakképző Iskola és Kollégium);

- új intézménytípusként a közoktatást kiegészítő, a hátrányos helyzet leküzdését elősegítő tanodák (Sashalmi Tanoda Általános Iskola). Bővebben I. www.tanodahalozat.hu (W4).

A jeles személyiségekről elnevezett közoktatási intézmények esetében változás történt. Korábban elsősorban közismert történelmi személyiségek, írók, költők, művészek nevével találkozhattunk, manapság viszont egyre gyakoribb, hogy országosan nem - vagy kevéssé - ismert személy a névadó, aki viszont a szűkebb régió, a település vagy az iskola számára valamilyen szempontból példakép. Ugyancsak megjegyzendő, hogy az egyházi iskolák nagyszámú újraindulásával ismét szerepet kaptak az 1948 és 1990 közötti időszakból számüzött felekezeti nevek.

Iskolanevek gyakori szereplői voltak és maradtak pl. a következők: Ady Endre, Arany János, Bartók Béla, Deák Ferenc, Gárdonyi Géza, József Attila, Kodály Zoltán, Kossuth Lajos, Lorántffy Zsuzsanna, Leövey Klára, Móra Ferenc, Petőfi Sándor, Rákóczi Ferenc, Zrínyi llona. (1948 és 1990 között: Kilián György, Korvin Ottó, Kun Béla, Marx Károly, Münnich Ferenc, Zalka Máté stb.)

A katolikus iskolák névadásában pl. a következő nevekkel találkozunk: Páduai Szent Antal, Árpád-házi Szent Piroska, Szent Bazil, Szent Benedek, Don Bosco, Szent Cecilia, Szent Erzsébet, Néri Szent Fülöp, Szent György, Szent József, Szent László, Szent Margit, Szent Norbert, Pál apostol (az intézménynévben: Pál Apostol), Sancta Maria. Rudolph Kolping szellemiségét és sajátos nevelési módszerét alkalmazva, számos fővárosi és vidéki katolikus iskola viseli a Kolping nevet, pl. Budapesti Kolping Katolikus Általános Iskola, Gimnázium és Sportgimnázium. (Más felekezetek iskolanévadásával külön pontban foglalkozunk.)

A korpuszban szereplő nem közismert személynevek: pl. Bajza Lenke, Benka Gyula, Bezerédj Amália, Bonifert Domonkos, Dalmady Győző, Dienes Valéria, Huszka Hermina, Kaszap Nagy István, Laschober Mária, Libor Ilona, Návay Lajos, Sánta Erzsébet, Szabó Dénes, Id. Szabó István, Uzoni Péter, Vári Emil, Telegdi Kata, Wilczek Frigyes, Zay Anna, Zimándy Ignác stb. Örvendetes elmozdulás, hogy a két nem képviselői a korábbi, „kanonizált" iskolanevekhez képest itt kiegyensúlyozottabb arányban szerepelnek.

\subsection{Gyakorlóiskolák}

A felsőoktatási intézmények gyakorlóiskoláinak névszerkezete eltérő, nem csupán elemeinek sorrendiségében, hanem a birtokviszony jelöltségében is:

Budapesti Fazekas Mihály Gyakorló Általános Iskola és Gimnázium;

ELTE Trefort Ágoston Gyakorló Gimnázium;

ELTE Radnóti Miklós Gyakorló Általános Iskola és Gyakorló Gimnázium;

DE Kossuth Lajos Gyakorló Gimnáziuma és Általános Iskolája;

SZTE Gyakorló Gimnázium és Általános Iskola; 
Eszterházy Károly Egyetem Gyakorló Általános, Közép-, Alapfokú Müvészeti Iskola és Pedagógiai Intézet.

Helyesírási megjegyzés: a korábbi különírással szemben az AkH. ${ }^{11} 112$. pontja - utóbb: az AkH. ${ }^{12}$ 118. pontja - alapján a szabályzat szójegyzéke már 1984 óta tartalmazza a gyakorlóiskola, gyakorlógimnázium formákat. (Hasonlóan a HKSz. ${ }^{1988}$, az MHSz. ${ }^{1999}$, az AkH. ${ }^{11}$ és az MHSz. ${ }^{2017}$ szótári része.)

\subsection{Két tanítási nyelvü oktatási intézmények}

Külön csoportot alkotnak a két tannyelvű oktatási intézmények. Ennek egyik oka maga a tipológia besorolás észszerű indoka, a másik oka viszont helyesírási. Az AkH. ${ }^{11} 119 .$, valamint az AkH..$^{12}$ 117. pontja egyértelműen eligazít a tőszámnév + képzett melléknév esetében. Itt ugyan nem szerepel a kétnyelvü - két tannyelvü összetétel, illetve szókapcsolat ilyetén szembeállítása, de a szótári részben megtaláljuk őket. Ennek ellenére még ma is léteznek ettől eltérő formában bejegyzett intézmények, az utóbbi alakulat egybeírásával: Szabó Lőrinc Kéttannyelvü Általános Iskola és Gimnázium; Szabó Magda Magyar-Angol [sic!] Kéttannyelvü Általános Iskola. A jelentéstömörítő összetétel helyett újabban általánossá vált a szintaktikailag és helyesírásilag is tagolt forma: két tannyelvü $\rightarrow$ két tanítási nyelvü, ezzel kiküszöbölve a normasértést. A névváltoztatást szemlélteti pl. a korábbi Ganz Ábrahám Kéttannyelvü Gyakorló Szakközépiskola és Szakiskola esete: ennek érintett névrésze [...] Két Tanítási Nyelvü [...] szerkezetté módosult.

Ugyanennek a szabálynak az alkalmazására van szükség akkor is, amikor az intézmény nevében megadják a működő évfolyamok számát: Balassi Bálint Nyolcévfolyamos Gimnázium (helyesen: Nyolc Évfolyamos). Számjeggyel írva megkerülhető ez a helyesírási buktató: Csokonai Vitéz Mihály 12 Évfolyamos Általános Iskola és Gimnázium.

\subsection{Nemzetiségi iskolák vagy nemzetiségi nyelven is oktató intézmények}

Általában terjedelmesebb névalakulatok: Bolgár Nemzetiségi Nyelvoktató Iskola; Dózsa György Német Nemzetiségi Nyelvoktató Általános Iskola; Gustave Eiffel Francia Óvoda, Általános Iskola és Gimnázium; Nikola Tesla Szerb Tanítási Nyelvü Óvoda, Általános Iskola, Gimnázium és Diákotthon; Szlovák Tannyelvü Óvoda, Általános Iskola, Gimnázium és Kollégium.

Az oktatás (alap)nyelvét tekintve egy intézményen belül működhet kétféle képzés: egynyelvű (magyar nyelvű) és két tannyelvű képzés is, amit az iskola neve a következőképpen tükröz: Általános, Magyar-Angol Két Tanítási Nyelvü, Alapfokú Müvészetoktatási Iskola és Napközi Otthonos Óvoda. Előfordul három nyelvi képzési forma: Újlak Utcai Általános, Német Nemzetiségi és Magyar-Angol Két Tanítási Nyelvü Iskola.

\subsection{Egyházi, felekezeti iskolák}

A különböző egyházak, felekezetek iskolanevei szerkezetüket, nyelvi formájukat tekintve azonosak a nem egyházi (állami, önkormányzati polgári) közoktatási intézmények névalakulataival: Baár-Madas Református Gimnázium, Általános 
Iskola és Kollégium; Zsámbéki Premontrei Keresztelő Szent János Általános Iskola, Gimnázium, és Alapfokú Múvészeti Iskola; Miskolci Görögkatolikus Általános Iskola; István Király Baptista Általános Iskola; Lauder Javne Zsidó Közösségi Óvoda, Általános Iskola, Középiskola és Zenei Alapfokú Múvészeti Iskola; Vajda Péter Evangélikus Gimnázium. (Megjegyzés: a korábbi különírás helyett a görögkatolikus egybeírását - az egyház kérésének megfelelően - kodifikálta az AkH. ${ }^{12}$ és az MHSz. ${ }^{2017}$.)

\subsection{Birtokviszonyt tartalmazó nevek}

A birtokviszonyt tartalmazó nevekben a birtokos jelző - több szó közbeékelése révén - elválik a jelzett szótól (ill. több birtokszó esetén: a jelzett szavaktól): Budapesti Komplex Szakképzési Centrum Erzsébet Királyné Szépészeti Szakgimnáziuma; Dunaújvárosi Szakképzési Centrum Lorántffy Zsuzsanna Szakgimnáziuma, Szakközépiskolája és Kollégiuma; Magyar Táncmüvészeti Egyetem Nádasi Ferenc Gimnáziuma és Kollégiuma.

\subsection{Idegen írásmódú szóalakot tartalmazó nevek}

Ebben a meglehetősen ritka névtípusban főleg latin szavak, kifejezések szerepelnek vezérszóként: Britannica Angolnyelvü [sic! - vö. MHSz. ${ }^{2017}$ ] Nemzetközi Általános Iskola és Gimnázium; Euro-Oktaéder Szakközépiskola; Facultas Humán Gimnázium [sic! - vö. A szabályzati háttér c. pontot]; Patrona Hungariae Általános Iskola, Gimnázium, Diákotthon és Alapfokú Múvészetoktatási Intézmény; Constantinum Katolikus Óvoda, Általános Iskola, Gimnázium, Szakgimnázium, Kollégium.

\subsection{Kifejező fantázianeveket tartalmazó iskolanevek}

Hagyományosan, a kialakult és rögzült szokásjog alapján az iskolanevek megfeleltek egyfajta "hivatalos" stílusnak. A korábbi névadási gyakorlathoz képest formabontó típusnak tarthatjuk ezeket az ötletes, hangulatos, kifejező vezérszókat, fantázianeveket tartalmazó alakulatokat: Móra Ferenc Általános Iskola és Micimackó Napköziotthonos Óvoda (kettős névadás); Burattino Általános és Szakképző Iskola, Gyermekotthon; Csillagösvény Waldorf Általános Iskola és Alapfokú Müvészeti Iskola; Griff Szakközépiskola és Szakiskola; Haj-Tan Fodrászokat és Kozmetikusokat Oktató Szakképző Iskola; Mustármag Keresztény Óvoda, Általános Iskola és Gimnázium; Nebuló Általános Iskola; Piliscsabai Palánta Általános Iskola; Táltos Tehetséggondozó Általános Iskola, Gimnázium, Szakképző Iskola és Alapfokú Művészetoktatási Intézmény; Tett Szakképző Iskola és Gimnázium; Út a Harmadik Évezredbe Közgazdasági és Külkereskedelmi Szakközépiskola.

Érdekes altípus, amikor az utcanév az iskolanév „vezérszava” lesz. Minden bizonnyal a korábbi közkeletű, bizalmas megnevezési forma kodifikálásáról, "hivatalossá" válásáról van szó: Fodros Általános Iskola (a Fodros utcában); Kőbányai Harmat Általános Iskola (a Harmat utcában). Hasonló jellegű, de más eredetű névformák: Kék Általános Iskola (az iskolaépület alapszínéről; 1992 és 2016 között, azóta Arany János Általános Iskola), Kalász Suli Általános Iskola (Budakalász településen). 
Kettős tulajdonnév kötőjellel összekapcsolva: a Gazdagrét-Csíkihegyek Általános Iskola kettős tulajdonneve a lakótelep és az utca (Csíki-hegyek utca) nevére utal.

\subsection{Bonyolult alakulatok}

Az utóbbi két évtized jelentős struktúraváltozást hozott a közoktatási intézmények életében. Ennek számos oka lehetett: kényszerű átalakulás, átszervezés, összevonás, de sok esetben az alapintézmény képzési szintjének, szintjeinek kiterjesztése, akár lefelé, akár felfelé. A többféle képzési formát és szintet magukban foglaló iskolák hivatalos neve tárgyszerü pontossággal rögzíti mindezeket. Ily módon a címszerű és cégszerü megnevezésekhez képest rendkívül hosszú - akár 15-20 szóból álló -, esetenként igen bonyolult alakulatok jönnek létre. Egyes alapító okiratok rögzítik a teljes és a rövid nevet is:

Balázs Győző Református Gimnázium, Egységes Müvészeti Szakgimnázium és Magyar-Angol Két Tanítási Nyelvü Múvészeti Általános Iskola, Alapfokú Müvészetoktatási Iskola (okiratban is rögzített rövid neve: Balázs Győző Református Gimnázium);

Bárczi Gusztáv Óvoda, Általános Iskola, Szakiskola, Készségfejlesztő Iskola, Fejlesztő Nevelés-Oktatást Végző Iskola, Kollégium, Egységes Gyógypedagógiai Módszertani Intézmény (Kaposvár);

Éltes Mátyás Általános Iskola, Óvoda, Készségfejlesztő Iskola, Kollégium, Egységes Gyógypedagógiai Módszertani Intézmény;

Gyermekház Általános Iskola, Gimnázium, Kereskedelmi, Vendéglátó, Idegenforgalmi, Informatikai Szakiskola és Alapfokú Müvészetoktatási Intézmény (rövid neve: Gyermekház Iskola).

Az iskolanevek esetében ritka megoldás, ha a közigazgatási forma (kerület, körzet, mikrotérség stb.) vagy a közös igazgatásra utaló kifejezés - vagy utolsó példánk tanúsága szerint több kifejezés - is része a névnek:

Budapest VII. Kerületi Baross Gábor Általános Iskola;

Dunaszegi Körzeti Általános Iskola;

Mikrotérségi Általános Iskola és Napköziotthonos Óvoda;

Bátaszék-Alsónyék-Pörböly Mikrotérségi Bölcsőde, Óvoda, Általános Iskola, Alapfokú Müvészetoktatási Intézmény, Gimnázium és Pedagógiai Szakszolgálat;

Közös Igazgatású Közoktatási Intézmény Tóth Pál Általános Iskolája, Mosolyvár Óvodája és Bölcsődéje;

Kaposvári Kodály Zoltán Központi Általános Iskola Toldi Lakótelepi Tagiskolája.

\subsection{Alapítványi iskolák}

Az alapítványi formára való utalás az iskola nevében is tükröződhet: Autizmus Alapítvány Iskolája; Humánus Alapítványi Általános Iskola; Tatay Sándor Alapítványi Gimnázium; Trívium Alapítványi Szakközépiskola és Szakiskola. Vannak olyan intézmények, amelyek nevükben nem tüntetik fel ezt a státust: Facultas Humán Gimnázium [sic!]. 


\subsection{Speciális képzést folytató középiskolák}

Megint más típust képviselnek azok a névalakulatok, amelyek valamilyen speciális képzést folytató intézményt jelölnek, és szóhasználatukat tekintve ritkának, egyedinek minősíthetők: Európai Üzleti Ismeretek Szakközépiskolája; Leonardo Média Akadémia Informatikai Szakközépiskola és Gimnázium; Szondi György Szakközépiskola, Szakiskola és Speciális Szakiskola; Grassalkovich Antal Gyakorlatközpontú Szakiskola és Szakközépiskola, Képesség- és Tehetségfejlesztó Magán Általános Iskola, Középiskola, Alapfokú Múvészeti Iskola és Kollégium.

Az utóbbi példánál maradva, a szakiskolák és a szakközépiskolák természetszerűleg gyakorlatközpontúak a gimnáziumokkal szemben, de bizonyára nyomós oka van, hogy ily módon hangsúlyozzák ezt a tényt. Találkozunk a humán melléknévvel is: Selye János Humán Szakközépiskola; Kolumbusz Humángimnázium. Az utóbbi, egybeírt formával szemben a MHSz. ${ }^{2017}$ a különírt változatot ajánlja. Ugyanitt szerepel a reálgimnázium összetétel is, ezt tartalmazó névalakulatot azonban nem találtam a korpuszban.

\section{5. Összegzés}

A korpusz elemzésével megállapíthatjuk, hogy manapság a közoktatási intézmények névformája, névszerkezete a korábbinál sokszínűbb, változatosabb. Helyesírási szabályzatunk 10. és 11. kiadásának megjelenésekor az intézménynevek kategóriája még viszonylag könnyen kezelhető, problémamentes csoport volt, benne az iskolanevek három fö típusa: a számmal, a személynévvel, illetőleg a hely(ség)névvel jelölt intézménynév. Az 1980-as években elindult az a folyamat, amelynek keretében az eredetileg csupán számmal jelölt alapfokú intézmények személynévi előtagot kaptak. Az iskolák ekkor még általában tiszta profilúak voltak, de 1990 után ez fokozatosan megváltozott, és a névforma követte, leképezte a feladat- és funkcióbővülést. A mai intézménynevek igyekeznek minél pontosabban tükrözni a képzési kínálatot, emiatt jönnek létre a terjedelmes, bonyolult alakulatok. A névforma - az iskola szintjének megjelölése mellett - utalhat az intézmény egyházi, alapítványi, gyakorlóiskolai vagy egyéb speciális jellegére, nemzetiségi vagy két tannyelvű voltára. A vizsgálat a tipológiai vonatkozásokon kívül névtani, lexikológiai és helyesírási tanulságokkal járt.

\section{Irodalom}

AkH. ${ }^{10}=$ Magyar Tudományos Akadémia 1954. A magyar helyesírás szabályai. 10. kiadás. Akadémiai Kiadó. Budapest.

AkH. ${ }^{11}$ = Magyar Tudományos Akadémia 1984. A magyar helyesírás szabályai. 11. kiadás. Akadémiai Kiadó. Budapest. 
AkH. ${ }^{11 / 11}$ = Magyar Tudományos Akadémia 1994. A magyar helyesírás szabályai . 11. kiadás, Tizenegyedik (szótári anyagában bővített) lenyomat. Akadémiai Kiadó. Budapest.

AkH. ${ }^{12}$ = Magyar Tudományos Akadémia 2015. A magyar helyesírás szabályai. 12. kiadás. Akadémiai Kiadó. Budapest.

Bozsik Gabriella 1999-2000. Az intézménynevek helyesírásának alakulása az akadémiai helyesírási szabályzatok alapján (1832-1994). In: Bozsik Gabriella - V. Raisz Rózsa (szerk.) Helyesírás és tanárképzés. Eszterházy Károly Főiskola Magyar Nyelvészeti Tanszéke. Eger. 40-45.

HKsz. ${ }^{1988}$ = Deme László - Fábián Pál (szerk.): Helyesírási kéziszótár. Akadémiai Kiadó. Budapest.

MHSz. ${ }^{1999}$ = Deme László - Fábián Pál - Tóth Etelka (szerk.): Magyar helyesírási szótár. Akadémiai Kiadó. Budapest.

MHSz. ${ }^{2017}$ = Tóth Etelka (szerk.): Magyar helyesírási szótár. Akadémiai Kiadó. Budapest.

\section{Internetes hivatkozások}

W1 - IskolákListája.eu. www.iskolaklistaja.eu (2020. 02. 20.)

W2 - Nemzeti Pályaorientációs Portál. https://palyaorientacio.munka.hu/ intezmenyek/keresok/kozoktatas (2020.07. 05.)

W3 - Közösségi Szolgálat Portál. www.kozossegi.ofi.hu/School/Detail (2020. 04. 20.)

W4 - Magyarországi Tanodahálózat. tanodahalozat.hu (2020. 07. 05.) 